\title{
The Overview of Innovations in the Legal Framework and Organization of Correctional Service
}

\author{
Vilard Bytyqi ${ }^{1}$, Fitore Morina ${ }^{2 *}$ \\ ${ }^{1}$ Faculty of Public Safety, Kosovo Academy for Public Safety, Kosovo. \\ 2 Faculty of Law, University of Prishtina, Kosovo. \\ * Corresponding author e-mail: fitore.morina1@uni-pr.edu
}

\section{ARTICLE INFO}

Keywords:

Correctional Service;

Innovations; Legal

Framework; Organization

How to cite:

Bytyqi, V., and Morina, F. (2019). "The Overview of Innovations in the Legal Framework and Organization of Correctional Service," Hasanuddin Law Review, 5(1): 19-27

DOI:

10.20956/halrev.v5i1.1734

\begin{abstract}
The main institution in Kosovo that deals with the execution of criminal sanctions and it is Kosovo Correctional Service (KCS). Since its establishment, this institution has undergone numerous changes in the organizational field, as well as changes created by legal regulation. The recent trends occurring in correctional services in democratic societies have transformed these services in order to have a human approach and, in several cases constitute a decisive factor in the change in the behaviour of delinquents. Delinquents that have been convicted for serious crimes by criminal proceedings of final judgment, in order to rehabilitate through based programs on contents of rehabilitation, resettlement, and reintegration used a various method which will be treated in this paper. Considering legal changes which have occurred, these changes have affected executive bodies in charge of the execution of criminal sanctions. In this paper were applied several methods, such as individual case study, normative analysis, and qualitative methods. From the results of the treatment, we can see that through the legal changes made in this area of Correction have special importance. The correctional system as organized by the Correctional Service has advanced regarding the terms of legislation, influenced by the European system implemented in some countries in this field.
\end{abstract}

Copyright (C) 2019 HALREV. All rights reserved.

\section{Introduction}

With the proclamation of the new Criminal Code, ${ }^{1}$ the penalties regulatory system in Kosovo has changed. These changes have created the possibility of removing some principle provisions that were available until now, and also has had introduced reformulations of the regulations that are still available, also had provided the adjustments of other situations, which never before had the corrections from the legal system in Kosovo. Because these changes set in place at the same time many of these

1 Code No. 04/L-082 Criminal Code of the Republic of Kosovo, on April 20, 2012. 
Regulations, it may arrange the convictions that courts declare the guilt of any defendant.

Regarding the general of punishments separation, the structure of penalties types has remained the same that have been regulated by the Provisional Criminal Code of $\mathrm{Kosovo}^{2}$, as are provided: Principal penalties, Alternative penalties, and Additional penalties. With the adoption of the new Criminal Code has changed, among others, also the main types of sentences. The new solutions, types of sentences are life imprisonment sentence, the imprisonment sentence, and penalty. ${ }^{3}$

However, the regulation of alternatives sentences, as one of the types of convictions under the Criminal Code, the structure of these sentences has remained almost the same as the structure of the past that has provided the previous criminal code, except some little changes on a system that is foreseen as necessary. While the additional sentences after the changes and the availability of the new Criminal Code have overcome this structure, they provided these types of punishments:

1) Deprivation of the right to be elected; 2) The order of compensation for loss or damage;

3) Prohibition on exercising public administration or public service; 4) Prohibition on exercising a profession, activity or duty; 5) Prohibition of driving; 6) Obtaining a driver's license; 7) Confiscation; 8) Publication order of the judgment, and 9) Expulsion of a foreigner from the territory of the Republic of Kosovo. 4

With the adoption of the new Criminal Code, the institutes of criminal law have undergone overall changes: added several institutes, and the institutions that existed, have suffered several changes in specific ways, the types and subtypes of sentences have become indispensable to change several laws, which are directly related to the provisions of the available Penal Code. Also, changes have undergone by the Sanctions Execution of Criminal Law, where these additional changes that are done, were imposed by the changes, approved by the new Criminal Code, and also the law.

Considering legal changes which have occurred, these changes have affected on executive bodies in charge of the execution of criminal sanctions, and according to the Law, to Execution of Criminal Sanctions is Kosovo Probation Service and Kosovo Corrective Service (hereinafter, 'KCS'). In this research work, the subjects of study are the innovations of legal and organizational adjustments which have occurred in KCS, dealing with enforcement of criminal sanctions in Kosovo.

The legal changes made in the field of Correction have particular importance. The correctional system as organized by the Correctional Service has advanced regarding the terms of legislation, influenced by the European system implemented in some countries in this field. Also, changes have occurred in the area of available law, dealing directly with the convicted or pretrial detained person, held in detention centre and pretrial detention. It has received a considerable relevance in the implementation of Criminal law, in security management, control, and rehabilitation, re-socialization, and reintegration into society of all persons who have acted against the law.

Promulgate on July 6, 2003, with UNMIK Regulation 2003/25 and is valid from 6 April 2004.

Distinguish of the new Criminal Code, according to the Temporary Criminal Code of Kosovo, the main sanctions that include imprisonment sentence and the fine sentence were left again as the primary type of punishment but is provide that instead of long-term imprisonment, to insert the sentence of eternal imprisonment.

4 Compare of the current Code, to the earlier Criminal Code, except the fine sentences which as ultimate punishment, is also provided as an additional punishment. The order of loss compensation or damage it's not included as one of the types of other punishments. 


\section{Method}

This paper uses a normative legal research as well as an empirical research in law field. The objective of this research was to understand innovations in the legal framework and structural organization of KCS. This research is conducted in these stages: Identification of problem background, literary study; Collection of normative data through field observation as well as gathering data and information. This study used legal materials which consist of primary, secondary and tertiary research materials. To achieve a comprehensive legal conclusion, this study applies a statute and comparative approach. The data is analysis by using descriptive qualitative to answer the above problems.

\section{Background and Legal Framework under which Functions the KCS}

KCS was established immediately after the war, on 05 November 1999 initially opening the Prizren Detention Centre. National staff was mainly the staff that has worked before the war. In May 2000 the first new correctional staffs were recruited on a competitive basis. Correctional Service is a functional service and advanced in all areas and this has come as a result of the assistance of the international community since the establishment. ${ }^{5}$ The KCS, in co-operation with all partners of Justice and In Constant Adaptability with Kosovo laws, has mission to correct and re-socialize prisoners respecting their fundamental rights regardless of race, language and religion as well as providing a safe environment for staff, inmates and society. ${ }^{6}$

KCS deals and supervises with prisoners based on applicable laws of Kosovo and also in international instruments, other legal acts and regulations. As a legal base for the functioning and operation of this institution, there are Kosovo Criminal Code, the Law on Execution of Criminal Sanctions, Criminal Code Procedure of Kosovo, and juvenile justice, other international acts, and other laws and regulations.

The purpose of "execution of criminal sanctions is re-socialization of convicts into society and to prepare them for life, as well as for responsible behaviour. Execution of Criminal Sanctions also serves to protect society by preventing further offenses and prevent others from acts criminal offenses."7

KCS is the central organ of state administration, professional independence, ranking uniformed and armed partly under the Ministry of Justice responsible for carrying out the following activities:

a) The organization, implementing and supervising the execution of imprisonment and for life imprisonment;

b) The organization, implementation and supervision of the juvenile incarceration and educational measures, unless the code of juvenile justice has other requirements;

c) The organization of programs that contribute to the rehabilitation, preparation for release and long-term supervises of persons sentenced to imprisonment and for life imprisonment;

d) Risk crime assessment to determine needs for treatment of offenders;

5 Kosovo Correctional Service (2018). Background of Kosovo Correctional Service. Available from: https://shkk.rks-gov.net/faqe.aspx?id=Czi+IvhTsckdy3wWbE8z3g==El=BOII5FUynjpl5RZJJ8nW1g== [retrieved: December 10, 2018].

6 Ibid.

7 Article 4, Law No. 04 / L-149 on Execution of Criminal Sanctions, July 29, 2013. Promulgated by Decree No. DL-035-2013, date 16.08.2013 by the President of the Republic of Kosovo. 
e) Guidance and support to inmates at the end of their sentence;

f) Undertaking measures with the purpose of education and training of civil staff and correctional officers' employees;

g) The implementation of cooperation with relevant institutions, associations, and organizations that deal with problems of execution of criminal sanctions. ${ }^{8}$

\section{The Organizational Structure of the KCS and Working Conditions for Staff}

Traditionally prison systems have been regarded, particularly by the staff who work within them, as static and hierarchical organisations. They are seen as static in that their objectives are clear and unchanging. According to this perspective, prisons exist to execute the sentence of the court, which is that the offender should be deprived of his or her liberty. ${ }^{9}$ The task of prison staff is to implement that sentence in a decent and humane manner. In so far as this task never changes, the prison system can be described as a static organisation. Secondly, prison systems are hierarchical in that they are disciplined organisations in which orders are passed down from above and the responsibility of staff at lower levels is simply to obey these orders. ${ }^{10}$

In some western countries, the management of prisons was originally a responsibility which was given to retired military officers as a means of enhancing their pensions; a task which was mildly interesting but which still allowed plenty of time for other more gentlemanly activities. Many of the junior prison staff were themselves former service personnel and were at ease with this style of management, which expected little of them other than to maintain a constant routine. In other countries the management of the prison system was, and in some cases such as India remains even today, the responsibility of the police force. A posting to take charge of a prison often came about as an informal sanction as a result of some failing elsewhere. Bright police officers made sure that they completed their spell as a prison manager as quickly as possible before being transferred back to mainstream police duties. There was a variation of this model in the Soviet Union where the prison system was part of the Ministry of the Interior and the senior management of each prison was made up of officers in the Ministry of Interior militia. ${ }^{11}$

Currently in some Western European countries, such as Germany, prison directors must have a legal qualification and their tenure in prisons is but one part of their general training for higher appointments in the public service. In other jurisdictions, such as some parts of the United States, all senior public appointments, including the wardens or directors of jails and prisons, are either themselves subject to election or their appointments are in the gift of elected politicians. In other countries, such as the United Kingdom, prison governors or directors are administrative civil servants, most of whom spend their professional careers working in the prison system. ${ }^{12}$

8 The current Law on Execution of Criminal Sanctions in Kosovo distinct from the previous law for Execution of Criminal Sanctions (Law no. 03 / L-191, July 22, 2010, promulgated by Decree no. DL-0432010, from date 09.08 .2010 by President of the Republic of Kosovo) has provided additional responsibility within the activities of the Kosovo Correctional Service. On this case, except for points 2 and 3, other items are new regulations that came as a result of reform and expansion of the activities of this service in Kosovo.

9 Coyle, Andrew. (2002). Managing prisons in a time of change. London: International Centre for Prison Studies, p. 11.

10 Ibid.

$11 \quad$ Ibid., p. 17.

12 Ibid., p. 17-18. 
As in most European countries, the prison director should be coming from civilian staff. As opposed to these countries, here is not required as a professional career criterion in the prison system. These criteria are foreseen by law. Central Correctional Service Office is the main directory, which manages and controls the Correctional Service and all cases connected with the Correctional Service. Correctional Service may also have the Deputy General appointed by the procedure, conditions, terms, and duration for the DirectorGeneral.

The Correctional Service shall be managed by the General Director of the KCS (hereinafter as, The General Director). The General Director shall be appointed following an open competition by the Ministry of Justice in compliance with Civil Service provisions on the appointment of senior management posts within the Civil Service of the Republic of Kosovo. The General Director is heading, controls and manages the KCS in all matters connected with the Correctional Service. The General Director shall be appointed for a period of five (5) years with the possibility of reappointment. The General Director reports directly to the Minister for its work. Also, Correctional Institutions which we will treat below have their principal responsibility for relevant institutions.

Regarding article 206 of the current Law for Execution of Criminal Sanctions, on carrying out the duties of the KCS, operating these organizational are these basic units: Central Correctional Service Office in Prishtina; and Correctional Institutions. Central Correctional Service Office, conducts and oversees the legality of the works and operations of the organizational units of the Correctional Service and correctional institutions.

According to current law on Execution of Criminal Sanctions, there are these types of correctional Institution: Prisons, for the execution of imprisonment and for life imprisonment; Pretrial Detention Center, for the execution of pretrial detention and prison terms up to three (3) months; Women's Prison for the execution of a sentence of imprisonment, juvenile imprisonment enounce for women; The juvenile prisons, the execution of juvenile imprisonment; Educational - correctional institutions, for the execution of the educational measure of sending juvenile convicted in the correctional educational institution; Hospitals, prisons, treatment of pretrial detainees and convicted persons.

Regarding the expansion, the correctional institutions are as below: 13 Correctional Centre-Dubravë, Correctional Center for Women and Juveniles in Lipjan; Correctional Center-Smrekonicë; Pretrial Detention Centre in Prishtinë; Pretrial Detention Centre in Lipjan, Pretrial Detention Centre - Gjilan, Pretrial Detention Center in Peja, Pretrial Detention Center in Prizren, Pretrial Detention Center-Mitrovicë, High Security Prison.

According to the Regulation on Internal Organization of the Ministry of Justice, the duties and responsibilities of correctional institutions are to manage and supervise the prisoners, under the applicable laws of Kosovo and international instruments and also the other legal acts and regulations; cooperating with all partners of justice and constant adaptability with Kosovo laws, the purpose is to correct and re-socialize prisoners, respecting their fundamental rights, regardless of race, language, religion, and also provides a safe environment for staff, prisoners and society; plans and organize

13 For more see: Article 252 of the Law on Execution of Criminal Sanctions and Article 45, Regulation (GRK) No. 31/2013 Internal Organization to the Ministry of Justice (approved at the 156 meeting of the Government of the Republic of Kosovo with the decision number No. 01/156). 
programs that contribute the rehabilitation, training, preparation for release and longterm supervision of persons sentenced to imprisonment and long-term imprisonment etc.

Under the provisions of this Regulation, the number of employees in central and local bodies KCS, one thousand six hundred and twenty-six (1626). According to the reports of KCS in Kosovo's prisons currently, there are 1,756 prisoners. Correctional centre staff perform an important public service. Their work is crucial to providing order, safety and control in detention facilities, in ensuring that detainees are treated in a humane and just manner, and that their human rights are respected. In order to achieve these goals, correctional centre staff need to be trained, motivated and supported. Hence, good working conditions are necessary to ensure that correctional centre staff have sufficient resources and motivation to perform their duties. ${ }^{14}$

In general, material conditions in detention facilities are satisfactory. However, a number of things could be improved, primarily related to the size and capacity of cells. This situation could be greatly improved by reducing the occupancy rate of cells, thus ensuring that their size conforms to international standards. Other concerns include poor ventilation, unsuitable toilet and shower facilities in several facilities, and the poor state of repair of several facilities. As mentioned above, those facilities built in the 1960s cannot be enlarged due to their position in the town centres and in-between court and police buildings. Refurbishing them constitutes a short-term solution as it does not solve the inadequate space problems. Superficial renovations, such as painting walls and fixing water leakages caused by old plumbing systems, also only lead to temporary improvements. Therefore, the local institutions should as a long-term strategy invest in new detention facilities rather than continually refurbishing the old ones. ${ }^{15}$

\section{Correctional Institutions Types ${ }^{16}$}

The current Law on Execution of Criminal Sanctions has made a categorization regarding the level of security and the treatment of inmates, which provided that the correctional institutions can be close - typed, ${ }^{17}$ semi-open ${ }^{18}$ and open. ${ }^{19}$ Regarding the treatment law, relating to regulations for correctional institutions of the closed type, it contains a description of what these institutions have as elements of material and physical security, such as correctional officers armed, wall fences or fences, technical equipment and other security measures that ensure them against the escape of convicted people.

14 Organization for Security and Co-operation in Europe Mission in Kosovo (2010). The Conditions in Detention Facilities in Kosovo - First Assessment. Available from: https://www.osce.org/kosovo/73845? download=true [retrieved: December 1, 2018], p16, quoted in Coyle, A. 2002. A Human Rights Approach to Prison Management, International Centre for Prison Studies, United Kingdom.

15 Ibid., p. 19.

16 See: Law of Execution of Criminal Sanctions. Regarding the correctional institutions' types in Kosovo, applicable Law for Execution of Criminal Sanctions compared this field with the previous law, are generally the same adjustments.

17 According to available Law on Execution of Sanctions, penal institutions confined are: Correctional Center - Dubrava, High Prison Security, Pretrial Detention Centre- Lipjan (closed-type correctional institution, semi-open), Pretrial Detention Center -Prishtina, Pretrial Detention Center -Prizren, Pretrial Detention Center- Gjilan, Pretrial Detention Center- Peja, Pretrial Detention Centre Mitrovica.)

18 According to available Law for Execution of Criminal Sanctions, the semi-open type institution is Correctional Centre- Lipjan.

19 According to the available law for Execution of Criminal Sanctions, the open type institution is Correctional Centre in Smrekonica. 
Also, with the closed-types includes the prison of high security, for the execution of detention against people classified as very high risk, pretrial detainees classified as very high risk and for those sentenced to for life imprisonment. While semi-open type correctional institutions have elements of physical security in the form of supervising the movement and work of the convicted person, there are elements of material security that prevent the escape of convicted persons.

Regarding correctional Institutions of open type, it is regulated that these institutions do not have the materials or physical security elements that prevent the escape of convicted persons. The behaviour of the convicted persons is based on their self-discipline, personal responsibility, and the correctional staff supervises the movement and work of convicted persons. While according to the law in correctional Institutions of the close type it is regulated to hold at least one third (1/3) of the sentences of for life imprisonment of persons who have received this kind of conviction, in the final judgment and against them has begun the execution of enounced criminal sanctions.

\section{Observation of Correctional Institutions}

Correctional institutions continuously are on institutional inspection for the work which they are charged to carry on, and the actions are undertaken for it. The administrative supervision proceeds through the Central Office, which is provided particularly on the legality of work and effort, the legitimacy of acts in the directory competencies of the correctional institution, the efficiency, and adaptability of the work on the domain of correctional institutions.

Overseeing the provision of health care to prisoners is the responsibility of the Ministry of health, which in this case is the Ministry of Health. The education programs of convicted people and its implementation, is the responsibility of the Ministry of Education, Science and Technology. According to the Law on Execution of Criminal Sanctions, it is foreseen to establish a Professional Council. This Council intends to follow, to research and improve the system of execution of criminal sanctions and it is composed by several scientific institutions, courts, administrative bodies, professional associations, civil society and other institutions that deal with issues of crime and the education of convicted people.

Oversight of the Correctional institutions work, perform the internal inspectorate for correctional institutions. The Inspectorate supervises the implementation of regulations and professional work of correctional institutions, with the aim of obtaining a unique system of execution of criminal sanctions, the transfer of positive experiences, analysing and work monitoring of some organizational units' correctional institutions and deliver professional assistance to those units.

Administrative Instruction, ${ }^{20}$ issued by the Ministry of Justice sets the principles and details ways on the work of the inspector, time, method of the inspection, the inspection in special fields, inspection upon requirement, report on the investigation and procèsverbal. Some employees in the inspectorate are 5.21

The Internal Inspectorate of the Ministry of Justice (MoJ) assessed the security-related issues in the EU financed High Security Prison (HSP) and concluded that security, anticontraband measures and incident management are at a satisfactory level. The HSP has

20 Administrative Instruction MD-No.11 / 2013 on the manner of conducting an internal inspection in correctional institutions, was signed by the Minister of Justice, on date 10.12.2013.

21 See: Article 145, Regulation (GRK) No.31 / 2013 on Internal Organization of the Ministry of Justice). 
also improved the sports-activity programmes for inmates. Moreover, the objectives and actions related to prisoner treatment, staff development and infrastructure of the KCS strategy have been finalised; this includes the procedures for keeping records of inmates' phone calls. ${ }^{22}$

\section{Conclusion}

The Legal changes made in this area of Correction have special importance. The correctional system as organized by the KCS has advanced regarding the terms of legislation, influenced by the European system implemented in some countries in this field. Also, changes have occurred in the area of available law, dealing directly with the convicted or pretrial detained person, held in detention centres and pretrial detention. It has received a considerable relevance in the implementation of Criminal law, in security management, control, and rehabilitation, re-socialization, and re-integration into society of all persons who have acted against the law.

The KCS has a decisive role in the execution of criminal sanctions in Kosovo. Fitted with modern service, including a variety of programs for reintegration, and rehabilitation, KCS is consolidated as an institution and now has established a sufficient experience in handling cases with high professionalism and professional ethics. It has also added some prisons, which include High-Security Prison, which is a costly and major investment. It has provided for the internship of people with high penalties and who present a higher risk to community and society. Furthermore, is working on current prisons, on physical infrastructures, as well in addition to various programs for prisoners. Probation Service is trying to find the legal basis for the regulation of electronic surveillance of persons, whose movement is restricted by the court or parole panel. This segment has passed on the Assembly and is pending approval of the law.

Kosovo penal law has laid a solid foundation for successful rehabilitation of prisoners through the combined use of the open and closed prison systems, with their differential forms of security. As a whole, the KCS represents a disciplinary facility designed to alter prisoners' behaviour patterns. However, the concern for the rehabilitation of prisoners is not about prisoners' rights; it's about returning these individuals to being productive members of society, so that they may be useful.

\section{References}

Administrative Instruction MD-No. 08/2013 for the risk categorization at work for the Probation Service staff.

Administrative Instruction MD-No. 11/2013, to Method of Conducting Internal Inspection in Correctional Institutions.

Administrative Instruction of the Ministry of Justice for disciplinary procedures and measures for prisoners on correctional institutions in the Republic of Kosovo, 04.12.2009

Code for Juvenile Justice, Nr. 03 / L-193. Approved on April 20, 2012.

22 European Union Rule of Law Mission in Kosovo (EULEX) (2016). Compact Progress Report - Assessing Progress Between August 2015-June 2016. Available from: https://www.eulexkosovo.eu/eul/repository/docs/English-Report-2016.pdf [retrieved: December 5, 2018], p. 23. 
Code of Criminal Procedure. No.04 / L-123 approved on 13 December 2012. Promulgated by Decree DL-057-2012, dated 21.12.2012 by the President of the Republic of Kosovo.

Coyle, A. (2002). A Human Rights Approach to Prison Management. United Kingdom: International Centre for Prison Studies.

Coyle, A. (2002). Managing prisons in a time of change. London: International Centre for Prison Studies.

European Union Rule of Law Mission in Kosovo (EULEX). 2016. Compact Progress Report - Assessing Progress Between August 2015-June 2016. Available from: https://www.eulex-kosovo.eu/eul/repository/docs/English-Report-2016.pdf [retrieved: December 5, 2018].

GRK Regulation - No. 31/2013 for internal organization of the Ministry of Justice, approved at 156 Government meeting of the Republic of Kosovo with the decision number No.01 / 156 from date 13.11.2013, published on the Official Newspaper of the Republic of Kosovo / No. 56/27 December 2013, Prishtina.

Halili, Ragip (2017). Penologjia. Prishtina: AAB.

Kosovo Correctional Service. 2018. Background of Kosovo Correctional Service. Available from: https://shkk.rks-gov.net/faqe.aspx?id=Czi+IvhTsckdy3wWbE8z3g $==\mathcal{E} l=B O I I 5 F$ Uynjpl5RZJJ8nW1g $==$ [retrieved: December 10, 2018].

Law No. 03 / 1-191 on Execution of Criminal Sanctions, July 22, 2010. Promulgated by Decree No. Dl-043-2010, dated 09.08.2010 by the President of the Republic of Kosovo.

Law No. 04 / 1-149 for sanctions criminal execution July 29, 2013. Promulgated by Decree No. Dl-035-2013, on date 16.08.2013 by the President of the Republic of Kosovo.

Organization for Security and Co-operation in Europe Mission in Kosovo. 2010. The Conditions in Detention Facilities in Kosovo - First Assessment. Available from: https://www.osce.org/kosovo/73845? download=true [retrieved: December 1, 2018].

Penal Code of the Republic of Kosovo, Code No. 04 / L-82, April 20, 2012, available from January 1, 2013.

Provisional Criminal Code of Kosovo, approved on 6 July 2003 by UNMIK Regulation No. 2003/25, available from on April 6, 2004.

Recommendation (206) of the Council Ministers to member states on the European Prison Rules, approved by the Ministers Council on January 11, 2006, at the 952 meeting of Vice-Ministers.

Standards of Human Rights in Correctional Institutions in Kosovo. Kosovo Centre for Rehabilitation of Survivors Torture. Annual Report January - December 2011. Fourth Annual Report, February 2012, Prishtina.

\section{Conflict of Interest Statement:}

The author(s) declares that the research was conducted in the absence of any commercial or financial relationships that could be construed as a potential conflict of interest.

Copyright (C) 2019 HALREV. All rights reserved. 